\title{
The diversity and distribution of Holothuroidea in shallow waters of Baluran National Park, Indonesia
}

\author{
ARIF MOHAMMAD SIDDIQ, TRI ATMOWIDI", IBNUL QAYIM \\ Department of Biology, Faculty of Mathematics and Natural Sciences, Bogor Agricultural University. J1. Raya Darmaga Bogor 16680, \\ West Java, Indonesia. Tel./Fax. +62-251-8622833, `email: atmowidi@gmail.com \\ Manuscript received: 26 December 2015. Revision accepted: 28 January 2016.
}

\begin{abstract}
Siddiq AM, Atmowidi T, Qayim I. 2015. The diversity and distribution of Holothuroidea in shallow waters of Baluran National Park, Indonesia. Biodiversitas 17: 55-60. A study of the diversity and distribution of sea cucumber (Holothuroidea) in shallow waters at Baluran National Park, East Java, Indonesia was carried out from July until September 2015. The method used in this study was systematic transect in low tide condition. Samples were collected by hands at intertidal sites. Identification of sea cucumber species based on morphological ossicles. Twenty one species of Holothuroidea belonging two orders and four families were found in this study. The most dominant family found was Holothuriidae (16 species), followed by Stichopodidae ( 2 species), Synaptidae ( 2 species), and Chiridotidae (1 spesies). Four species (Holothuria olivacea, H. verrucosa, Labidodemas rugosum, and Chiridota smirnovi) are new record for Java waters and one species (H. papillifera) is a new record for Indonesian waters. Two morphospecies (H. aff. macroperona and Stichopus cf. monotuberculatus) need reconfirmation to species level. The highest abundance species of Holothuroidea was found at under rock with 15 species. Whereas, the highest number of individuals was found in seagrass areas with 5457 individuals. $H$. atra has extensive habitat distribution, such as seagrass, macroalgae, coral reef, dead coral, sand, and under rock.
\end{abstract}

Key words: Baluran National Park, distribution, diversity, Holothuroidea, shallow waters

\section{INTRODUCTION}

Sea cucumbers (Holothuroidea: Echinodermata) are found in various substrates and depths (Sluiter 1901; Samyn et al. 2006; Woo et al. 2013). Approximately, 300 species of sea cucumber were reported in the shallow to deep sea of Indonesian waters (Sluiter 1901; Clark and Rowe 1971; Massin 1996, 1999; Massin and Tomascik 1996; Purwati and Wirawati 2012). Diversity of Holothuroidea in Indonesian waters has been reported, such as Wirawati et al. (2007), Yusron (2006, 2007, 2009a, b, 2010, 2012), Setyastuti (2009), Yusron and Susetiono (2006, 2010), Purwati and Wirawati (2008, 2009, 2011, 2012), Selanno et al. (2014). In marine ecosystem, Holothuroidea help the process of decomposition of organic matter in sediments and produce nutrients in the food chain (Bakus 1973).

Some species of Holothuroidea have a high economic value, known as Trepang or Beche-de-Mer. In Asian tropical and sub-tropical waters, Actinopyga, Bohadschia, Holothuria, and Stichopus are exploited as food and medicinal product industry. Whereas, in temperate waters of Japan, Apostichopus japonicus is the most captured by fishery (Conand and Muthiga 2007). Some species of Holothuroidea are listed into Appendix II CITES (Convention on the International Trade in Endangered Species) (Polidoro et al. 2011), because the population of the species declines every year in the world, including in the Indonesian waters (Purwati 2005; Setyastuti and Purwati 2015).
Recently, 11 species of sea cucumbers are reported as new records in Johor strait and 10 species are potentially as new species (Woo et al. 2014; Ong and Wong 2015). Kamarudin et al. (2010) also stated that approximately 80 species of sea cucumbers are found in Malaysian waters. The diversity of sea cucumber in Indonesian waters has been studied only in some areas, while exploitations of some species that have economic value occur continuously (Purwati and Wirawati 2009). Expeditions of Holothuroidea in Indonesian waters, including international expeditions, were conducted in the eastern of Indonesia (Sluiter 1901; Massin 1996; Massin 1999). Study of sea cucumber in national parks in Indonesia is still limited.

Baluran National Park (BNP) is a conservation area located in the Situbondo district, East Java, Indonesia. Geographically, this park is directly adjacent to two open waters, Bali and Madura straits. BNP is located in the northern coast of Java, which has a variety of substrates and diverse marine habitat, such as sand, mud, rocks, dead coral, seagrass, macroalgae and coral reefs. This paper describes the diversity, distribution, and habitats of each Holothuroidea in shallow waters of BNP.

\section{MATERIALS AND METHODS}

\section{Study sites}

The study was conducted from July to September 2015 in shallow waters of BNP. Samplings of Holothuroidea were taken in low tide condition in three locations, i.e. Bama, Air Karang, and Bilik (Figure 1). Bama (100,000 
$\left.\mathrm{m}^{2}, 7^{\circ} 50^{\prime} 72.1^{\prime \prime} \mathrm{S}, 114^{\circ} 27^{\prime} 80.4^{\prime \prime} \mathrm{E}\right)$ was dominated by the substrate of sand and dead coral and covered by several types of seagrass and macroalgae. Coral reefs were found in the intertidal edge of the area. Air Karang $\left(112,000 \mathrm{~m}^{2}\right.$, $7^{\circ} 47^{\prime} 04.8^{\prime \prime} \mathrm{S}, 114^{\circ} 25^{\prime} 190$ "E) was dominated by coral reef and rocks with sand substrates, muddy-sand, and dead coral. Whereas, Bilik $\left(60,000 \quad \mathrm{~m}^{2}, \quad 7^{\circ} 45^{\prime} 28.1^{\prime \prime S}\right.$, $\left.114^{\circ} 22^{\prime} 75.5^{\prime \prime} \mathrm{E}\right)$ was dominated by rocks with a substrate of sand and mud. Dead corals as well as coral reefs were found in the intertidal edge of the area.

\section{Observation of Holothuroidea diversity}

The method used to observe Holothuroidea in each location was transect at low tide condition. Observations of sea cucumbers were conducted in transect those set up in intertidal sites. We recorded the number of individuals and their coordinates of each sea cucumber found by Global Positioning System (GPS), as well as the characters of the habitats (coral reef, dead coral, macroalgae, seagrass, under rock, and sand). Specimens of Holothuroidea collected were anaesthetized by $7.5 \%$ Magnesium Chloride solution and then preserved in $70 \%$ denatured ethanol.

\section{Identification of Holothuroidea specimens}

Identification of species Holothuroidea was conducted based on morphological ossicles using Clark (1938), Cherbonnier (1952), Cherbonnier (1988), Clark and Rowe (1971), Massin (1996), Massin (1999), Samyn and Massin (2003). Technique for ossicles observation based on Purcell et al. (2012). Ossicles observations were carried out using Leica DMRBE microscope. All specimens of Holothuroidea were deposited in the Oceanography Research Centre, Jakarta, Indonesia.

\section{Data analysis}

Diversity of Holothuroidea was analyzed using Shannon-Wiener index $\left(\mathrm{H}^{\prime}\right)$, evenness index $\left(\mathbf{J}^{\prime}\right)$, and species dominant (D) performed by PAST software (http://folk.uio.no/ohammer/past) version $2.17 \mathrm{c}$. Distribution pattern of Holothuroidea was constructed by mapping of each coordinate points of Holothuroidea in their habitats. Data of Holothuroidea coordinates and their habitats were exported into shape file format and processed by QGIS software (http://qgis.org/). Basic maps were obtained from Indonesian Geospatial Agency (http://www.bakosurtanal.go.id/peta-rupabumi/).

\section{RESULTS AND DISCUSSION}

\section{The diversity of Holothuroidea}

Twenty one species of Holothuroidea belonging two orders (Aspidochirotida and Apodida), four families, and eight genera were found in this study. The family Holothuriidae (16 species) has highest species richness, followed by Stichopodidae (2 species) and Synaptidae (2 species), and Chiridotidae (1 species) (Table 1). The highest number of individuals found in BNP was Holothuria atra (9935 individuals). The species is found in various substrates, such as seagrass, macroalgae areas, dead coral, coral reef, rock, and sand. Species Chiridota smirnovi was found at under rock with lowest abundance. In Bama, dominant species found was $H$. atra $(9875$ individuals), whereas in Air Karang and Bilik were Opheodesoma grisea (835 and 198 individuals), respectively. The highest diversity of Holothuroidea was found in Bilik $\left(\mathrm{S}=15, \mathrm{H}^{\prime}=1.335, \mathrm{~J}=0.506\right)$, followed by Air

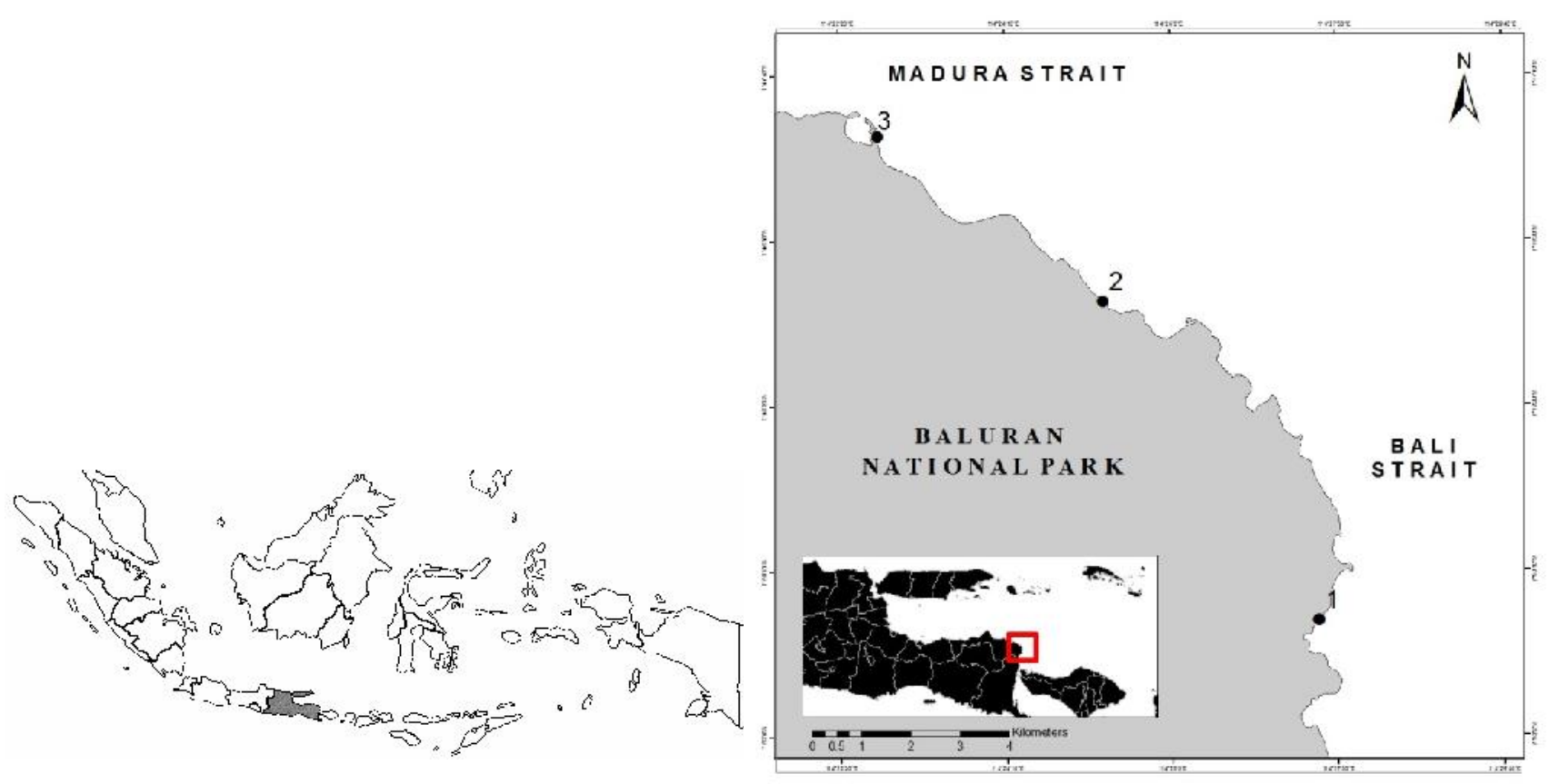

Figure 1. Study sites in shallow waters of Baluran National Park, East Java, Indonesia: 1. Bama, 2. Air Karang, 3. Bilik 
Karang $\left(\mathrm{S}=13, \mathrm{H}^{\prime}=0.666, \mathrm{~J}^{\prime}=0.259\right)$, and Bama $(\mathrm{S}=9$, $\left.\mathrm{H}^{\prime}=0.146, \mathrm{~J}=0.066\right)$. In contrast, the highest dominance was found in Bama $(\mathrm{D}=0.951)$, followed by Air Karang $(\mathrm{D}=0.761)$, and Bilik ( $\mathrm{D}=0.404)$, respectively (Table 1).

\section{Spatial distribution pattern of Holothuroidea}

Distribution of Holothuroidea related to habitat composition (Figure 2). Holothuriidae and Synaptidae were found in Air Karang, Bama, and Bilik. Stichopodidae was found in Air Karang and Bilik, while Chiridotidae in Bilik. Family Holothuriidae dominated in all habitats, such as macroalgae, seagrass, coral reef, dead coral, under rock, and sand. In contrast, Chiridotidae has limited habitat at under rock. Commonly, Stichopodidae is found at under rock, while Synaptidae is found in seagrass and macroalgae. Only few individuals of Stichopodidae and Synaptidae have been found in dead coral.

\section{Habitat preference of Holothuroidea}

From 21 species Holothuroidea found in shallow waters of BNP, seven species (33\%) were found at under rock. Fourteen species $(67 \%)$ were found at more than one habitat, i.e., coral reef, dead coral, macroalgae, sand, and seagrass. The highest abundance of Holothuroidea is found at under rock (15 species), followed by dead coral (10 species), sand (9 species), seagrass (7 species), macroalgae (5 species), and coral reef ( 2 species). In contrast, the highest number of individuals of Holothuroidea was found in seagrass (5457 individuals), followed by sand (2658 individuals), coral reef (1014 individuals), dead coral (998 individuals), macroalgae (920 individuals), and at under rock (194 individuals) (Figure 3).

\section{Discussion}

Based on this study, diversity of Holothuroidea in shallow waters at BNP is higher than at Moti Island (8 species; Yusron 2007), Minahasa (8 species; Yusron 2009), West Lombok (14 species; Purwati and Wirawati 2009), Prigi Bay (7 species; Purwati and Wirawati 2012), South China Sea, Sulu Sea and Sulawesi Sea (12 species; Woo et al. 2013), but lower than in Central Moluccas (22 species; Selanno 2014), Ambon (53 species; Massin 1996) and Spermonde Archipelago (56 species; Massin 1999). Four species (H. olivacea, $H$. verrucosa, L. rugosum, and $C$.

Tabel 1.Number of individuals and species of Holothuroidea collected in shallow waters at Baluran National Park

\begin{tabular}{|c|c|c|c|c|c|}
\hline \multirow{2}{*}{$\begin{array}{c}\text { Order: Family } \\
\text { Species }\end{array}$} & \multicolumn{4}{|c|}{ Number of individuals } & \multirow{2}{*}{ Habitat } \\
\hline & $\mathrm{AK}$ & $\mathrm{BM}$ & BL & Total & \\
\hline \multicolumn{6}{|l|}{ Aspidochirotida: Holothuriidae } \\
\hline Actinopyga echinites Jaeger, 1833 & 0 & 0 & 3 & 3 & $\mathrm{DC}, \mathrm{SG}$ \\
\hline Bohadschia marmorata Jaeger, 1833 & 0 & 2 & 2 & 4 & $\mathrm{CR}, \mathrm{DC}, \mathrm{MA}$ \\
\hline B. similis Semper, 1868 & 2 & 0 & 2 & 4 & DC, MA, SG \\
\hline Holothuria (Selekonthuria) erinaceus Semper, 1868 & 0 & 3 & 0 & 3 & UR \\
\hline H. (Halodeima) atra Jaeger, 1833 & 15 & 9875 & 45 & 9935 & $\mathrm{CR}, \mathrm{DC}, \mathrm{MA}, \mathrm{SD}, \mathrm{SG}, \mathrm{UR}$ \\
\hline H. (Mertensiothuria) hilla Lesson, 1830 & 4 & 0 & 39 & 43 & SG, UR \\
\hline H. (Mertensiothuria) leucospilota Brandt, 1835 & 14 & 16 & 8 & 38 & DC, UR \\
\hline H. (Mertensiothuria) papillifera Heding inMortensen, 1938 & 0 & 0 & 2 & 2 & UR \\
\hline H. (Thymiosycia) impatiens Forskal, 1775 & 26 & 2 & 1 & 29 & UR \\
\hline H. (Thymiosycia) aff. Macroperona Clark, 1938 & 0 & 0 & 7 & 7 & DC, UR \\
\hline H. (Stauropora) fuscocinerea Jaeger, 1833 & 10 & 0 & 0 & 10 & DC, UR \\
\hline H. (Stauropora) olivacea Ludwig, 1835 & 8 & 0 & 0 & 8 & UR \\
\hline H. (Lessonothuria) pardalis Salenka, 1867 & 0 & 4 & 3 & 7 & SD, UR \\
\hline H. (Lessonothuria) verrucosa Salenka, 1867 & 4 & 0 & 0 & 4 & UR \\
\hline H. (Metriatyla) scabra Jaeger, 1833 & 7 & 4 & 0 & 11 & $\mathrm{SD}, \mathrm{SG}$ \\
\hline Labidodemas rugosum Ludwig, 1875 & 0 & 0 & 4 & 4 & UR \\
\hline \multicolumn{6}{|l|}{ Aspidochirotida: Stichopodidae } \\
\hline Stichopus cf. monotuberculatus Quoy \& Gaimard, 1833 & 4 & 0 & 5 & 9 & DC, UR \\
\hline S. quadrifasciatus Massin, 1999 & 2 & 0 & 0 & 2 & $\mathrm{DC}, \mathrm{UR}$ \\
\hline \multicolumn{6}{|l|}{ Apodida: Synaptidae } \\
\hline Opheodesoma grisea Semper, 1868 & 835 & 121 & 198 & 1154 & $\mathrm{DC}, \mathrm{MA}, \mathrm{SG}$ \\
\hline Synapta maculata Chamisso \& Eisenhardt, 1821 & 28 & 102 & 6 & 136 & SG, MA \\
\hline \multicolumn{6}{|l|}{ Apodida:Chiridotidae } \\
\hline Chiridota smirnovi Massin, 1996 & 0 & 0 & 1 & 1 & UR \\
\hline Number of individual & 959 & 10129 & 326 & 11414 & \\
\hline Number of species & 13 & 9 & 15 & & \\
\hline Shannon-wiener index (H') & 0.666 & 0.146 & 1.335 & & \\
\hline Evenness index (J') & 0.259 & 0.066 & 0.506 & & \\
\hline Dominance index (D) & 0.761 & 0.951 & 0.404 & & \\
\hline
\end{tabular}

Reference: Clark (1938); Cherbonnier (1952, 1988); Massin (1996, 1999); Samyn and Massin (2003). Note: AK=Air Karang, $\mathrm{BM}=\mathrm{Bama}, \mathrm{BL}=\mathrm{Bilik}, \mathrm{CR}=$ coral reef, $\mathrm{DC}=$ dead coral, $\mathrm{MA}=$ macroalgae, $\mathrm{SG}=$ seagrass, $\mathrm{SD}=$ sand, $\mathrm{UR}=$ under rock 


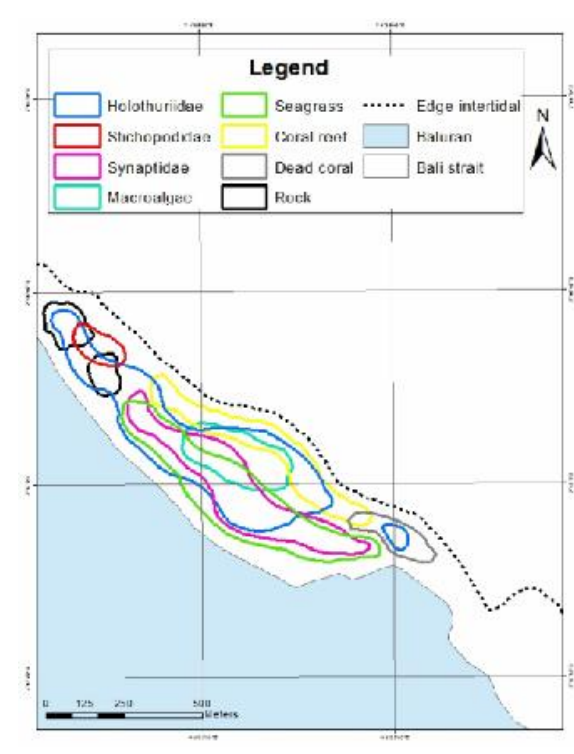

$\mathbf{A}$

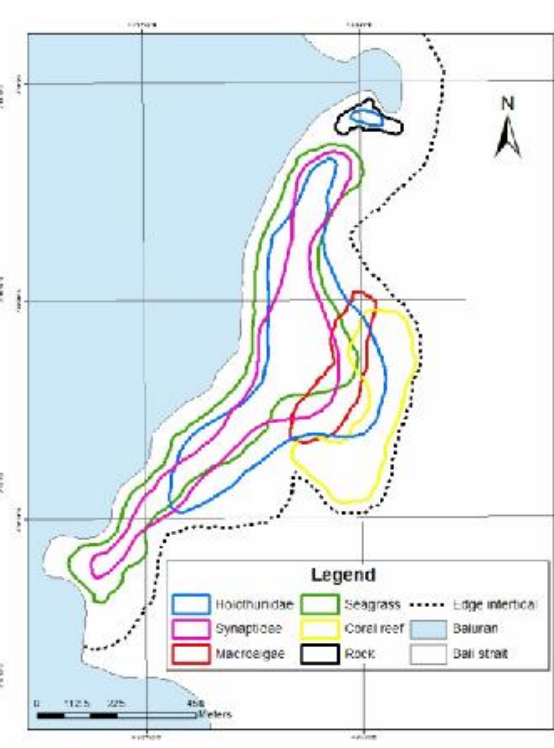

B

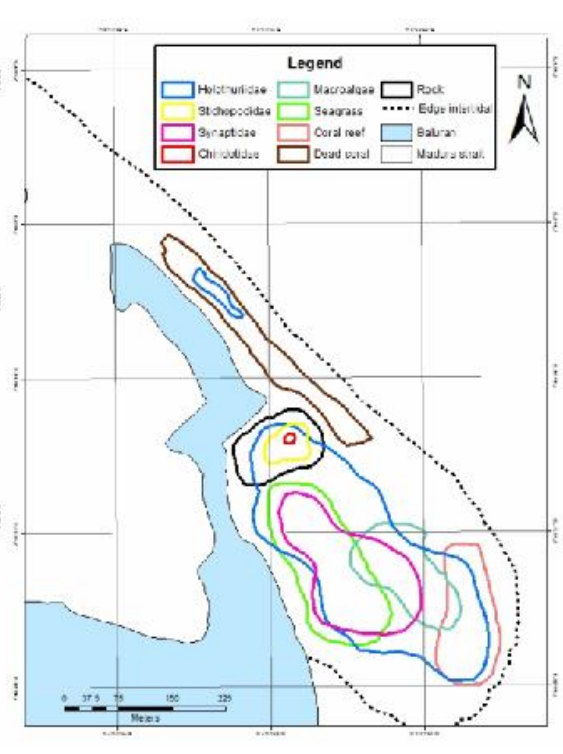

$\mathbf{C}$

Figure 2. Spatial distribution of Holothuroidea species in shallow waters at Baluran National Park: A. Air Karang, B. Bama, and C. Bilik

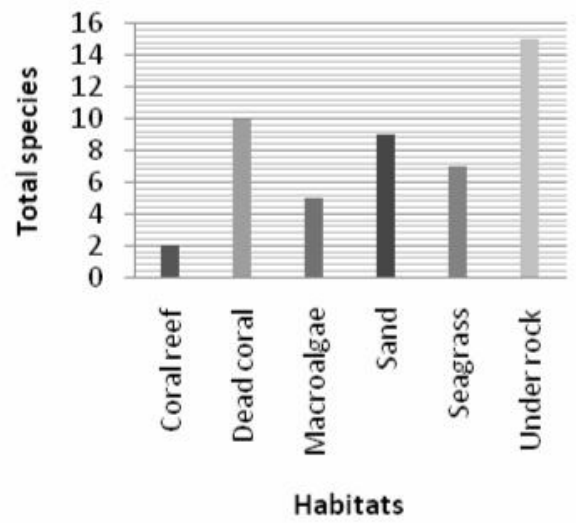

A

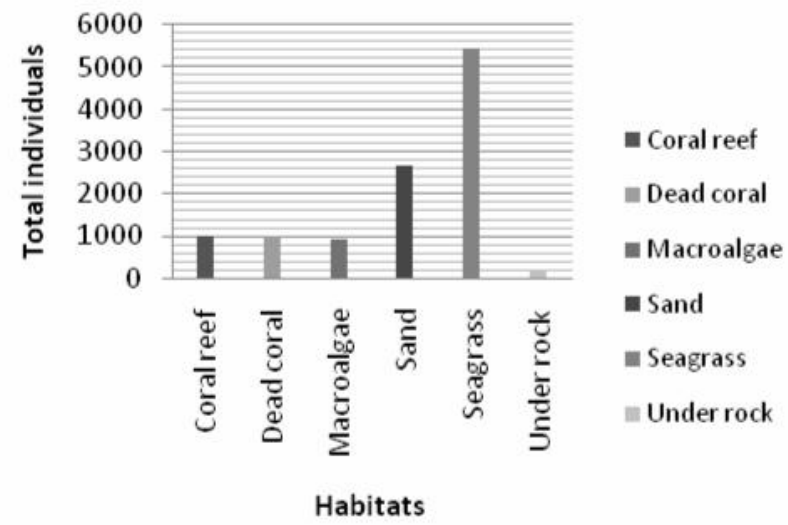

B

Figure 3. Number of species (A) and individuals (B) of Holothuroidea found at five habitats in BNP

smirnovi) are new record in Java waters. Previously, the species were reported in Sulawesi, Nusa Tenggara, and Irian Jaya waters (Sluiter 1901; Massin 1996; Massin 1999; Purwati and Wirawati 2011). One species (H. papillifera) is a new record in Indonesia. Previously, the species was reported in the Red Sea (Gardaqha, Abu Sadaf, and Abu Fanadir) (Samyn and Massin 2003). Two morphospecies (H. aff. macroperona and S. cf. monotuberculatus) need reconfirmation to species level. Based on ossicles morphology, $H$. aff. macroperona is similar with $H$. macroperona. This species is only distributed in Western Australia (Clark 1938). S. cf. monotuberculatus is similar with S. monotuberculatus (Cherbonnier 1952) and the species widely distributed across the tropical Indo-West Pasific (Massin et al. 2002).

Distribution of sea cucumber was influenced by microhabitat. Woodby et al. (2000) reported that some sea cucumbers prefer harder substrate, such as sand, rocks and dead coral related to their locomotion. Based on this study, approximately $71.4 \%$ species of Holothuroidea (family Chiridotidae, Stichopodidae, and some species of Holothuroiidae) was found at under rocks around the reef. Purwati and Wirawati (2012) also reported in Prigi Bay, six species of sea cucumbers $(H$. atra, H. erinaceus, $H$. mactanensis, Afrocucumis africana, Chiridota sp., and Polycheira rufescens) were found at under rock and some individuals in sand-boulders. In shallow waters of BNP, dead coral and sand are the habitat prefered by Holothuroidea. The similar result also was reported by Woo et al. (2013), in South China Sea, Sulu Sea, and Sulawesi Sea, about $83 \%$ sea cucumber belonging family Holothuriidae, Synaptidae, and Stichopodidae prefered dead coral and sand as their habitat. 
The highest number of individuals was found in seagrass areas, while the lowest at under rock. $H$. atra has a highest individual number, mainly in seagrass areas. It is showed by high dominance index with density 5-15 individuals $/ \mathrm{m}^{2}$. In the tropical area, $H$. atra has a density 5-35 individuals $/ \mathrm{m}^{2}$ (Bakus 1973). Totally, 9935 individuals of the species are found in shallow waters of BNP. When low tide conditions, this species immerse themselves in the sand substrates. Some individuals were found with sand grain attached in their body. H. atra is the common species from Indonesian waters (Yusron 2006, 2007, 2009; Purwati and Wirawati 2009, 2012) and Indo Pasific area (Massin 1999; Jontila 2014). In BNP, C. smirnovi is only found one individu. Previously, the species was reported in Ambon water (Massin 1996).

Eighteen species of order Aspidochirotida (A. echinites, B. marmorata, B. similis, H. erinaceus, H. atra, H. hilla, $H$. leucospilota, $H$. papillifera, $H$. impatiens, $H$. aff. macroperona, $H$. fuscocinerea, $H$. olivacea, $H$. pardalis, $H$. verrucosa, $H$. scabra, $L$. rugosum, $S$. cf. monotuberculatus, and S. quadrifasciatus) dominated in shallow water of BNP. Domination of order Aspidochirotida also was reported in Western Indian Ocean with 28 species and some species are new records (Conand et al. 2010). While, order Apodida in BNP has lower species richness (O. grisea, Synapta maculata, and C. smirnovi). The species were found in seagrass, macroalgae, dead coral, and under rock. S. maculata (Synaptidae) occupied in seagrass areas (Yusron 2006; Yusron and Susetiono 2006). Color variations of the species was found in this study. $O$. grisea has more than three color variations. Purwati and Wirawati (2008) also reported $O$. grisea from Timor Island, East Nusa Tenggara has three color variations. Massin (1999) stated that color variations of $O$. grisea depend on the nature of sediment type.

Marine conditions of Baluran National Park as a conservation area, can not ensure the existence of Holothuroidea from over exploitation. Many fishermen are periodically enters in this area, especially in Air Karang, and take some Holothuroidea that have high economic value. Approximately, 58 species of Holothuroidea in the world are listed as the fisheries commodities (Conand and Muthiga 2007; Choo 2008; Purcell et al. 2012), and 27 species of them are found in Indonesian waters (Purwati 2005; Setyastuti and Purwati 2015). Some species found in the study, such as $A$. echinites, $B$. marmorata, $B$. similis, $H$. atra, H. hilla, $H$. impatiens, $H$. leucospilota, $H$. scabra and $S$. quadrifasciatus were reported as fisheries commodities. Conand et al. (2014) reported population of H. scabra decrease and the species is listed as endangered category of Red List Threatened Species (IUCN 2015). H. scabra is endangered aquatic species in Indonesia (Ubaidillah et al. 2013). Cultivation or aquaculture of some species that have high commercial value, such as $H$. scabra (Conand and Muthiga 2007; Leopold et al. 2015) can be conducted in Baluran National Park. In addition, sustainable expeditions of sea cucumber are needed in Indonesian waters, especially in deep sea waters.

\section{ACKNOWLEDGEMENTS}

We deep thank to the Director and staff of Baluran National Park for permission and use facilities during the research. We also thank to biology team for assistance in the field. Finally, thank to Ismiliana Wirawati and staff in the laboratory of Echinodermata, Research Center for Oceanography (LIPI Indonesia) for their assistance in identification process of the specimens.

\section{REFERENCES}

Bakus GJ. 1973. The biology and ecology of tropical holothurians. in: Q.A. Jones and R. Endean (eds). Biology and geology of coral reefs. Vol. I. Academic Press, London.

Cherbonnier G. 1952. Les Holothuries de Quoy et Gaimard. Memorie de 1 'Institut royal des sciences naturelles de Belgique 2 serie 44: 1-50.

Cherbonnier G. 1988. Echinodermes: Holothurides. Faune de Madagascar 70: 1-292.

Choo PS. 2008. Population status, fisheries and trade of sea cucumbers in Asia. In V. Toral-Granda, A. Lovatelli, M. Vasconcellos (eds). Sea cucumbers. A global review of fisheries and trade. FAO Fish Aquacult Tech 516: 81-118.

Clark HL. 1938. Echinoderms from Australia. Printed For The Museum, Cambridge.

Clark AM, Rowe FWE. 1971. Monograph of shallow-water Indo-West Pacific Echinoderms. Trustees of The British Museum Zoology, London.

Conand C, Muthiga NA. 2007. Commercial Sea cucumbers: a review for the Western Indian Ocean. WIOMSA 5: 66.

Conand C, Michonneau F, Paulay G, Bruggemann H. 2010. Diversity of the Holothuroidea fauna (Echinodermata) at La Reunion (Western Indian ocean). WIOJMS 9 (2): 145-12.

Conand C, Polidoro B, Mercier A, Gamboa R, Hamel JF, Purcell S. 2014. The IUCN Red List assessment of aspidochirotid sea cucumbers and its implications. SPC Beche-de-mer Info Bull 35: 3-7.

Jontila JBS, Balisco RAT, Matillano JA. 2014. The sea cucumbers (Holothuroidea) of Palawan, Philippines. AACL Bioflux 7 (3): 194206.

Kamarudin KR, Rehan AM, Hashim R, Usup G. 2010. Review An update on diversity of sea cucumbers (Echinodrmata: Holothuroidea) in Malaysia. Malay Nat J 62 (3): 315-334.

Leopold M, Ham J, Kaku R, Gereva S, Raubani J, Moenteapo Z. 2015. Spatial sea cucumber management in Vanuatu and New Caledonia. SPC Beche-de-mer Info Bull 35: 3-18.

Massin C, Tomascik T. 1996. Two new Holothurians (Echinodermata: Holothuroidea) from an Anchialine Lagoon of an uplifted atoll, Kakaban Island, East kalimantan, Indonesia. Raffles Bull Zool 44 (1): 157-172.

Massin C. 1996. Results of the Rumphius Biohistorical Expedition to Ambon (1990). Part 4. The Holothuroidea (Echinodermata) collected during the Rumphius Biohistorical Expedition. Zool Verh 307: 1-53.

Massin C. 1999. Reef dwelling Holothuroidea (Echinodermata) of the Spermonde Archipelago (South-West Sulawesi, Indonesia). Zool Verh 329: 1-144.

Massin C, Zulfigar Y, Tan Shau Hwai A, Rizal Boss SZ. 2002. The genus Stichopus (Echinodermata: Hoothuroidea) from the Johor Marine Park (Malaysia) with the description of two new species. Biologie 72: 73-99.

Ong JY, Wong HPS. 2015. Sea cucumbers (Echinodermata: Holothuroidea) from Johor Straits, Singapore. Raffles Bull Zool 31: 273-291.

Polidoro B, Tognelli M, Harwell H, Elfes C, Cepeda A, Gonzalez-Maya JF, Zarate-Charry DA, Alvarado JJ, Benavides M, Conand C, Ortiz EP, Gamboa R, Hamel JF, Mercier A, Purcell S, Toral-Granda V. 2011. IUCN Red List workshop for sea cucumbers. SPC Beche-demer Info Bull 34: 65.

Purcell SW, Samyn Y, Conand C. 2012. Commercially important sea cucumbers of the world. FAO Species Catalogue for Fishery Purposes, Rome. 
Purwati P. 2005. Teripang Indonesia: Composition species and fisheries history. Oseana 30 (2): 11-18. [Indonesian]

Purwati P, Wirawati I. 2008. Synaptidae (Echinodermata: Apodidae) from Lamun Elnusa, Timor Island, East Nusa Tenggara. Oldi 34 (3): 371 384. [Indonesian]

Purwati P, Wirawati I. 2009. Holothuriidae (Echinodermata, Holothuroidea, Aspidochirotida) of shallow waters of West Lombok Part I. Genera Holothuria. J Oseanolgi 2 (1/2): 1-25. [Indonesian]

Purwati P, Wirawati I. 2011. Holothuriidae (Echinodermata, Holothuroidea, Aspidochirotida) of shallow waters of West Lombok Part II. Genera Actinopyga, Bohadschia, Labidodemas, Pearsonothuria. J Oseanologi 3: 1-10. [Indonesian]

Purwati P, Wirawati I. 2012. Sea cucumbers of Teluk Prigi, Southern Coast of Java Province. Oldi 38 (2): 241-254.

Samyn Y, Massin C. 2003. The holothurians subgenus Mertensiothuria (Aspidochirotida: Holothuriidae) revisited. J Nat Hist 37 (20): 2487 2519.

Samyn Y, Vandenspiegel, Massin C. 2006. Taxonomie des Holothuries des Comoros. Abc Taxa 1: 130

Selanno DAJ, Natan YL, Uneputty PrA, Lewerissa YA. 2014. Ecological Study of Sea Cucumber Central Moluccas. IOSR-JAVS 7(1): 21-28.

Setyastuti A. 2009. Sea Cucumber (Echinodermata: Holothuroidea Stichopodidae, Holothuriidae, Synaptidae) of West Seram, Maluku, Indonesia. Oldi 35: 369-396.

Setyastuti A, Purwati P. 2015. Speciest list of Indonesian trepang. SPC Beche-de-mer Info Bull 35: 19-25.

Sluiter CPh. 1901. Die Holothurien der Siboga Expedition. Siboga Exped 44: $1-142$

Ubaidillah R, Marwoto RM, Hadiaty RK, Fahmi, Wowor D, Mumpuni, Pratiwi, R, Tjakrawidjaja AH, Mudhiono, Hartati ST, Heryanto, Riyanto A, Mujiono N. 2013. Endangered of aquatic biota in Indonesia. Direktorat Konservasi Kawasan and Jenis Ikan, Ditjen Kelautan, Pesisir, and Pulau-Pulau Kecil, Kementerian Kelautan and
Perikanan, Lembaga Ilmu Pengetahuan Indonesia, Jakarta. [Indonesian]

Wirawati I, Setyastuti A, Purwati P. 2007. Sea cucumber members of Famili Stichopodidae (Aspidochirotida, Holothuroidea, Echinodermata) collection of Puslit Oseanografi Lembaga Ilmu Pengetahuan Indonesia Jakarta. Oldi 33: 355-380. [Indonesian]

Woo SP, Yasin Z. Ismail SH, Tan SH. 2013. The Distribution and Diversity of Sea Cucumbers In The Coral Reefs Of The South China Sea, Sulu Sea, and Sulawesi Sea. Deep-Sea Res II 96: 13-18.

Woo SP, Teh CP, Norhanis MR, Nithiyaa N, Amelia-ng PF, Zulfigar Y, Tan SH. 2014. Sea cucumber species of the Merambong Shoal with notes on the distribution and habitat of the dominant species. Malay Nat J 66: 139-145.

Woodby D, Smiley S, Larson R. 2000. Depth and habitat distribution of Parastichopus californicus near Sitka, Alaska. Alaska Fish Res Bull 7: 22-32.

Yusron E. 2006. Echinodermata in Saleh Bay, Sumbawa, West Nusa Tenggara. Oldi 40: 43-52. [Indonesian]

Yusron E, Susetiono. 2006. Composition of speceis Echinodermata in Tanjung Pai Padaido waters, Biak Numfor-Papua. J Fish Sci 8 (27): 282-289.

Yusron E. 2007.Resources of Teripang (Holothuroidea) in Moti Island, North Maluku. Oldi 33: 111-121. [Indonesian]

Yusron E. 2009a. The diversity of Echinodermata in Kuta Bay, West Nusa Tenggara. Oldi 13: 45-49. [Indonesian]

Yusron E. 2009b. Biodiversity of Echinodermata Fauna in Selat Lembeh Waters, Bitung-North Sulawesi. Oldi 35 (2): 217-229. [Indonesian]

Yusron E. 2010. The diversity of Echinodermata in Likupang Waters, North Minahasa, Noth Sulawesi. Ilmu Kelautan 15 (2): 85-90. [Indonesian]

Yusron E, Susetiono. 2010. The diversity of Echinodermata in Ternate Waters, North Maluku. Oldi 36 (3): 293-307. [Indonesian]

Yusron E. 2012. Biodiversity of Echinoderms in Talise Water, North Minahasa. Bawal 4(3): 185-193. [Indonesian] 